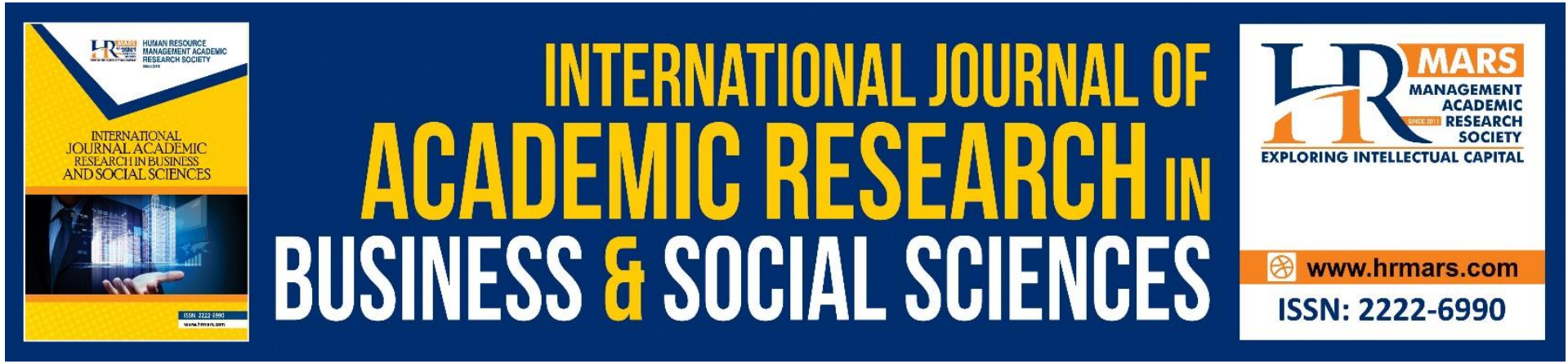

\title{
Linguistic Miracles in The Noble Qur'an
}

Aly Reda Aly Darwish, Mohamed Fathy Mohamed Abdelgelil, Mohd A'Tarahim Mohd Razali, Ahmad Fauzi Hassan, Mohd Shaifulbahri Abdullah

To Link this Article: http://dx.doi.org/10.6007/IJARBSS/v11-i9/11137 DOI:10.6007/IJARBSS/v11-i9/11137

Received: 07 July 2021, Revised: 01 August 2021, Accepted: 28 August 2021

Published Online: 19 September 2021

In-Text Citation: (Darwish et al., 2021)

To Cite this Article: Darwish, A. R. A., Abdelgelil, M. F. M., Razali, M. A. M., Hassan, A. F., \& Abdullah, M. S. (2021). Linguistic Miracles in The Noble Qur'an. International Journal of Academic Research in Business and Social Sciences, 11(9), 1248-1258.

\section{Copyright: @ 2021 The Author(s)}

Published by Human Resource Management Academic Research Society (www.hrmars.com)

This article is published under the Creative Commons Attribution (CC BY 4.0) license. Anyone may reproduce, distribute, translate and create derivative works of this article (for both commercial and non-commercial purposes), subject to full attribution to the original publication and authors. The full terms of this license may be seen at: http://creativecommons.org/licences/by/4.0/legalcode

Vol. 11, No. 9, 2021, Pg. 1248 - 1258

Full Terms \& Conditions of access and use can be found at http://hrmars.com/index.php/pages/detail/publication-ethics 


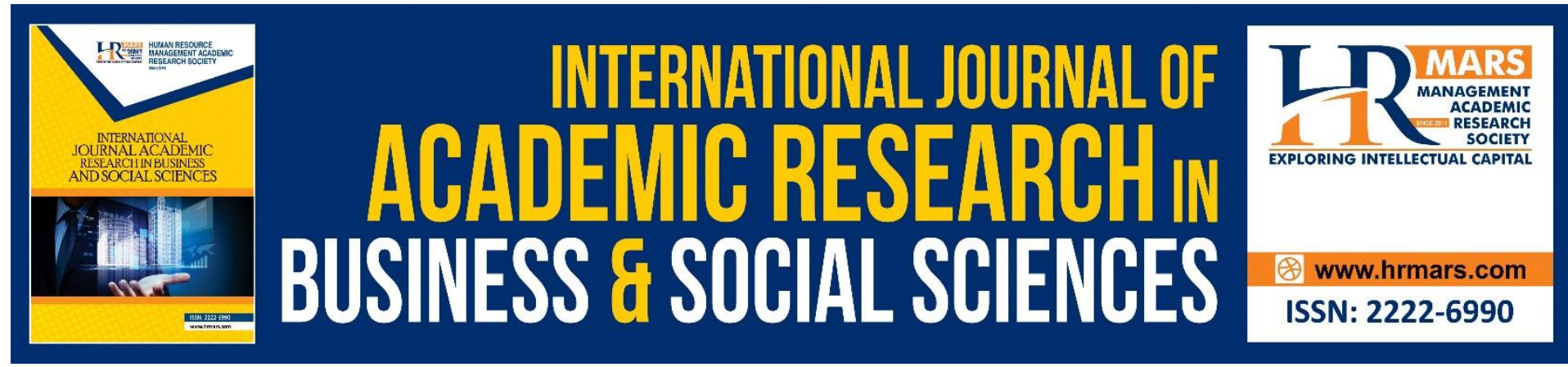

\title{
Linguistic Miracles in The Noble Qur'an
}

\section{Aly Reda Aly Darwish, Mohamed Fathy Mohamed Abdelgelil, Mohd A'Tarahim Mohd Razali, Ahmad Fauzi Hassan, Mohd Shaifulbahri Abdullah}

Faculty of Islamic Contemporary Studies (FKI), Sultan Zainal Abidin University (UniSZA),

21300, Terengganu, MALAYSIA.

Email:mfathy@unisza.edu.my

\begin{abstract}
The Holy Quran is the greatest miracle in the history of nations and messengers. Almighty Allah revealed it to His Prophet Muhammad, may Allah bless him and grant him peace. In addition, the way his style dazzled the minds and enlightened the hearts. The Holy Quran was a miracle in this pattern and that statement. The problem is that not many people are familiar with this pattern of eloquent language. Accordingly, the research aims to show the linguistic miracle in the Holy Quran. The research is based on the analytical method to track the places of linguistic miraculousness in the Qur'an and cast them within the criteria of linguistic miraculousness in the Qur'an. This research resulted in several results, including: The uniqueness of the Qur'anic style with these features is evidence of its divine source. The reason for the distinctiveness of the Qur'anic style is the divinity of its source, just as it is not possible in any way to emulate the style of the Qur'an, no matter how good command the emulator on Arabic have.
\end{abstract}

Keywords: Reasons, Eloquence, Style And Technique, Rhetoric, The Holy Quran.

\section{Introduction}

Praise be to Allah, we seek His help. Whomsoever Allah guides will never be led astray, and whomsoever Allah leaves astray, no one can guide. I bear witness that there is none worthy of worship but Allah (alone with no partners) and I bear witness that Muhammad is His slave and Messenger. To proceed, the honorable science is what is related to the Book of Almighty Allah in reading, explanation and education, how not, and it is the greatest book on the earth from which scholars have taken in all their branches of discovered sciences, jurists, grammarians and all scholars, it is the reference for all sciences. Moreover, Almighty Allah has ensured its preservation. Almighty Allah said,

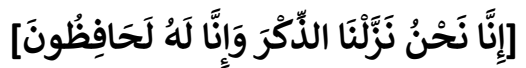
Indeed, it is We who sent down the Qur'an and indeed, We will be its guardian. (al-quran, alhijr, 15:9)

The noble Qur'an has been giving the nation, scholars and preachers benefits, lessons and miracles. It was interpreted in every era and in every country and it is still to this day illuminating the way for scholars. In it, the cosmic verses, the exhortation verses and the verses of rulings are manifested. It is miraculous in its pronunciation, in its meaning, in its 
words and in its grammar. Moreover, it will remain so until the doomsday. Therefore, we will talk about the miracles of the Qur'an.

\section{Foreword}

The Noble Qur'an is one of the miracles that distinguished the Prophet, may Allah bless him and grant him peace. Allah has challenged the eloquent Arabs at the time of prophecy, and this miracle continues and the challenge continues until the Day of Resurrection. Once Caliph Abu Bakr Al-Siddique found some of the companions of Musaylamah, the liar, after they returned to the religion of Allah, he asked them to recite to him something from the Qur'an of Musaylamah. They asked him to excuse them from that, but he refused unless they read something of it to him so that those who did not hear it could hear it, so they would know the merit and standard of what they are upon of guidance and knowledge. Therefore, they read to him what he said:

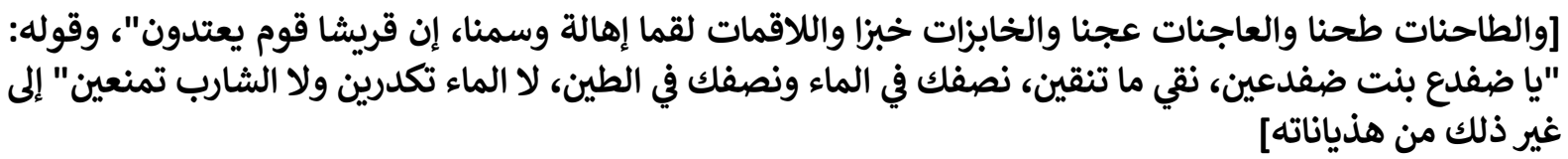

And so on from his delusions. Abu Bakr, May Allah be pleased with him, said: "pity you! What happened to you all? By God, this did not come out of God" (Ibn Katheer, 2007, 2/ 411). Caliph Al-Siddique, May Allah be pleased with him, realized through his delicate sense and his good psychological taste that the phrases and structures, the method of their formulation, and the peculiar character of the psyche of the one who said them came out. It is human nature and not from the Creator Almighty Allah. The difference between the Great Qur'an and human speech is like the difference between the Allah, Glory be to Him, and the creature. Therefore, his words are like lawful magic that controls the mind of the listener As well as robs the listener of his will and makes use of him for his own purposes. For this reason, the Qur'an was a miraculous one. Among the aspects of this miracle is what will be presented in the following aspects.

\section{Miracles in the Qur'an}

The Qadi Ayyad author of the Al-Shifa bi Ta'rif Huquq al-Mustafa discusses the miracles in the Qur'an, so he limits them to four:

The first: its good composition, the consistency of its word, its eloquence and its rhetoric, which are superior to what the Arabs have.

And the second: the image of its wondrous arrangement, the unique style that contradicts the styles of Arab speech, the techniques of its compilation and prose that came upon it, and its stopping at the syllables of a verse, and the end of the separation of its words and cutting off. There was no equal before it or after, and no one was able to match it.

And the third: what was included regarding to prophesies, what wasn't there and did not happen, so it has been found as it was reported based on reason that was told as the Almighty's saying:

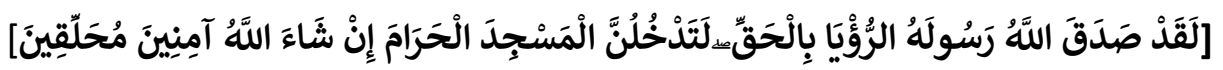

Certainly, Allah has showed to His Messenger the vision in truth. You will surely enter alMasjid al-Haram, if Allah wills, in safety. (al-quraan, al-fath, 48:27) and His saying

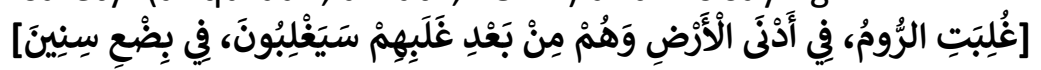

The Byzantines have been defeated. In the nearest land. However, they, after their defeat, will overcome. Within three to nine years. (Al-quraan, Al-Rum: 2-4), to the end of that is one 
of the hidden matters that the Qur'an told about before they happened, and they happened as he told them.

And the fourth: What it had told from the news of the centuries, the annihilated nations, and the former sharia, from which no single story was known except for the feat of the expert of the People of the Book who cut short his life in learning that. So almighty Allah revealed it to The Prophet, May Allah bless him, and he brought it in text. The world recognizes that it is authentic and true. In addition, the like of him, peace and blessings be upon him, he did not achieve any kind of education. Moreover, they knew that he, may Allah's prayers and peace be upon him, was illiterate, did not read or went to school.

This is what Qadi Ayyad mentioned in the variety of the miracles. We find the first two types related to the rhetorical aspect of the Qur'an. Although the first miracle is related to the composition of its words and their consistency with their eloquence, flawlessness and free from monsters. The second miracle is in the form of the systems, and despite the fact that they differ from them, we find them ending in the rhetorical aspect. As for the other two miracles, they relate to the truthfulness of prophesies contained in the Holy Qur'an. However, the first between these two relates to informing about the unseen incidents in the future, which only Almighty Allah knows. The second relates to telling about the past (Ayyad, 1421, 1/ 9).

The sayings of scholars differed in defining the miraculous aspects in the Holy Qur'an: some of them brought them to ten aspects, and some of them made more than that, and some of them made the types of miraculousness as one aspect and stood up for it and cited objections to others. Whoever traces these kinds of miraculousness mentioned by scholars both former and modern, finds many of them overlapping or similar. After extrapolation and verification, he can combine many of them. In addition, we find that many aspects revolve around the rhetorical interpretation and performance and the distinguished style of the Holy Qur'an in that... In addition, such miracles focus on the guidance in the Holy Qur'an and its goals in making humanity happy by bringing it out of darkness into light and bringing it to the abode of happiness and eternal bliss... Among the miracles are what is related to informing about the unseen. ... and what included references, indicators and allusions to the nature and convention of Allah in the universe, nature and life that Almighty Allah created.

\section{The rhetorical miracle in the Qur'an \\ Definition of Rhetoric (Al-Balaghah)}

The rhetoric (Al-Balaghah) in language: taken from (البلوغ), which means to reach and to end towards it; for example, it is said that I reached the place, so I ended there. Moreover, in the terminology: (Al-Balaghah) in speech: conveying the meaning to someone's heart in the best form of the words. (Muhammad, 2007, 1/ 118). In addition, it is said, an eloquent man and eloquent speech, i.e. eloquent, and an eloquent tongue, i.e. eloquent, and an eloquent man: good speech is eloquent, a man who communicates with the words using his tongue to express what is in his heart. (Ibn Manzoor, 1414, 2/ 544). Moreover, some of the later ones said, Al-Balaghah: expressing in a wonderful word the correct meaning without increasing or decreasing any word (Muhammad, 2007, 1/ 175). We find that the definitions of rhetoric mostly revolve around conveying the meaning to the heart of the addressee with an easy and concise phrase, taking into account the requirements of the listener's condition so that it affects himself, and conveys from it what the teller wants, which is indicated by the first definition and perhaps the most likely. 


\section{The Definition of Fasohah (Eloquence)}

Eloquence is what it means in language: (clear) appearance and statement. For example, the clear milk after frothing the foam appears. It is also said the brightest morning when sunlight appears and everything can be seen clearly. (Ibn Manzoor, 1414, 2/ 545). In addition, an eloquent tongue means fluent. Moreover, in the Noble Qur'an Moses speaks:

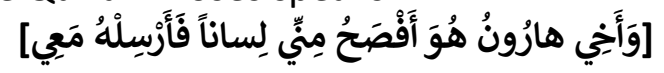

"And my brother Aaron - He is more eloquent in speech than I: so send him with me as a helper, (al-quraan, Al-Qasas: 34). The Fasohah (eloquence) in terminology: it is free from complexity, and the eloquence of the Qur'an: it is an Arabic word used to perform the meaning in an uncomplicated way. (Ibn Al-Qayyim, 1988, 1/ 9). We find that all definitions revolve around clarification and clearing up, with no complexity.

\section{The Difference between Fasohah (Eloquence) and Al-Balaghah (Rhetoric)}

It is said that they are successive on one meaning, and most of scholars went to the differentiation and said: Eloquence is one of the symptoms of words with the appropriateness of the meaning. While rhetoric is one of the symptoms of meaning, which is to supplement the meaning with the word that is understood. The rhetoric in the meanings and the eloquence in the words. It is said, an eloquent meaning and a rhetoric word. The difference between Eloquence and rhetoric is, "Eloquence is limited to describing words, and rhetoric is only a description of words with meanings. It is not said in a single word that does not indicate a meaning that is preferable to a rhetoric one, even if it is said it is eloquent. Each rhetoric speech is eloquent, but not all eloquent speech is rhetoric" (Al-Khafaji, 1894, 1/ 54).

If we review the verses of the Noble Qur'an from the beginning of Surat Al-Fatihah to the end of Surat Al-Naas on the definition of eloquence and rhetoric, and the conditions of eloquent words and rhetoric speech, we will find every verse in which eloquence and rhetoric have been mentioned in their best forms. In addition, if we find that the meanings of the words flow to the heart before the words dazzle us with their enchanting beauty. Whether in the Surahs and the verses that draw our attention to the horizons, to deduce Almighty Allah is the only Creator of this wonderful universe. On the other hand, verses related to the principle of resurrection on judgment day or anything related to organizing the affairs of the ruler with his subject, or rights of family and its members and other matters that the Holy Qur'an has taken over. All these verses have the bright color of the wonderful statement and verbal beauty in the simplest, clearest style and closest to the understanding and touching the heart. It was well known and still among scholars of rhetoric and of eloquence that there are certain matters and special situations in which the poet or writer is good at nothing else. Moreover, his psychological state plays a role in giving the features and advantages to his production. Therefore, some poets were known for the quality of praise and erotic poetry and others for satire and defamation. Others took precedence in terms of courage and describing wars and others in judgment and accuracy in expressing mental or psychological meanings. In addition, if someone left what he was doing and tried something he was not accustomed to, the value of his poetry and authorship would decrease. It may come with something that is denounced or abhorred. Hence, the proverb was set that Imru' al-Qays when he rides, the Nabigha when he gets afraid and Zuhair when he desires.

As for the upper class to adhere to eloquence and the height of the hump of rhetoric in every small and large matter, no matter how different topics, contrasting conditions and vast timeline, that is what we do not find in the authorship of any human being. Because human beings - as Ibn Atiyyah says - "are overwhelmed by ignorance, forgetfulness and amazement. 
It is known that no human being knows everything, and that is only for the Creator, His Majesty Almighty Allah who encompasses all the words. Therefore, the Qur'an was organized with the utmost eloquence." (Ibn Atiyyah, 1422,1/38) The one who follows the verses of the Noble Qur'an from those who know the meanings of rhetoric will find in it all its arts, from describing the many meanings with the few words, and from the types of emphasis, and the types of simile and representation until the proverbs. In addition the types of metaphors, impressive prefaces and foreword, syllables and commas, advancement and delay, separation and connection. As well as it is free from the rhetorical, irregular, stray, and repulsive word, and other types of eloquent and rhetorical arts so that the reader of the Holy Qur'an and its structures experienced in the arts of rhetoric does not see any of it except that he finds it the best that it can be. None of the rhetoricians, who have reached the pinnacle of rhetoric from among the Arabs, even if he is exhausted, is able to comprehend a few types of them. Whoever was familiar with the language of the Arabs and the arts of its eloquence, would have known the advantages of the eloquence of the Noble Qur'an and its miraculousness to the both human and Jinn.

\section{I'jaz ul Qasr (Limitation of summarization and synopsizing)}

I'jaz ul Qasr is one of rhetorical arts. Its example is a short chapter of the Noble Qur'an, which is Surat al-Kawthar, which is also the shortest chapter of the Qur'an. Despite its few limited words, it contained wonderful meanings, eloquence and wonderful rhetoric, which demands the confirmatory to what Almighty Allah, is saying in Quran,

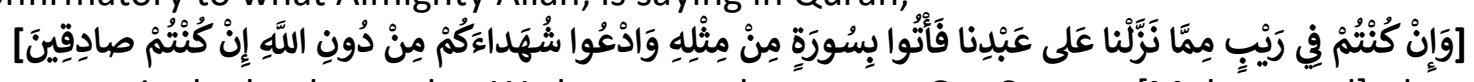

And if you are in doubt about what We have sent down upon Our Servant [Muhammad], then produce a surah the like thereof and call upon your witnesses other than Allah, if you should be truthful. (al-quran, Al-Baqarah: 23). Among these features and rhetorical points in Surat Al-Kawthar: The Almighty said,

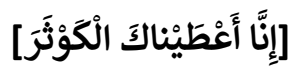

(Indeed, we have given you Al-Kawthar) (al-quraan, Al-Kawthar: 1). indicates a great gift that is attributed to a great giver. Moreover, whoever was like that, the blessing was great for him. In addition, with Kawthar meant a lot of goodness and welfare. In addition, from Kawthar, the believers from his Ummah will receive great goodness and pleasure until the Day of Resurrection, other than what Allah has promised and will give them in both worlds. Moreover, indeed it will be the advantages of glorification, submission and reward that only Allah knows. It is said that al-Kawthar is a special river, its water is sweeter than honey, and on its edges are glasses and cups of gold and silver as many as the number of stars in the sky. In addition, that Allah used plural pronoun (أَعْطَيْنَاكَ) as a subjective case, and he feels the greatness of divinity and Godhood. Giving is commensurate with the position of deism referred to with the pronoun veneration. Moreover, the $(\dot{\omega})$ in the second verse is learned from the meaning of causing two meanings: to give a lot of grants and blessings for a reason to thank and worship the One who is the great benefactor.

\section{Refinement and Consistency of the Qur'anic System}

By the systems of the Qur'an, it meant the method of composing its letters, words and sentences and casting them with its other components in an accurate form. Then the method of using these combinations for purposes with its components in an accurate form, and then the method of using these combinations for the purposes to talk about it to direct and guide the meanings in the clearest terms in the best context and the most beautiful composition. 
Badi' al-Zaman says, "If speech follows the example of reality and matches its composition completely, it will be accomplished to the fullest extent." (Badi' al-Zaman, 1998, 1/ 85). In the following examples, we shed light on this aspect: In this section, the Almighty says:

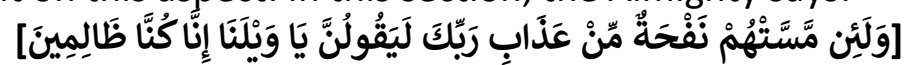

If but a breath of the Wrath of thy Lord do touch them, they will then say, "Woe to us! We did wrong indeed!" (al-quran, Al-Anbiya: 46). In the context of demonstrating human weakness in front of the might of the Creator, the Blessed and Exalted Almighty Allah, he wanted to show their weakness in the face of light and little torment. Therefore, he came up with words that all tend to show the purpose, which is a description of the torment with a few, so he brought the word (in) (إن) which indicates doubting its occurrence. In addition, he brought the word (touching) (المسّ) instead of injury or burn, as it is lower in rank and without hurting the flesh. Likewise, the word (a whiff) (نَفْحَةُّ) with its hint of the weakness and contempt of the torment and (from) (مِن) to describe few from a large group, so not all the torment came to them, but rather it is a slight passing whiff of a small part of the torment. Then the torment was not directed to the name indicative of oppression and tyranny, but rather it was directed to the finest name that indicates compassion, which is (Lord) (رب). Then the word Lord was directed to a loved one, which is the pronoun to address the Messenger of Allah may Allah's prayers and peace be upon him. In short, these all words are directed to one goal which is describing this torment as a small, light, insignificant and ignoble to show thus that the sinners regret and regret what they did when they are exposed to a slight whiff of God's torment. (If but a breath of the Wrath of thy Lord do touch them, they will then say, "Woe to us! We did wrong indeed!)".

\section{Advantages of Quranic Composition}

Among its advantages is its interest in the Qur'anic sentence and the selection of the appropriate location and spot for the expressive word. In addition to what we previously mentioned about the consistency between the phrase and the meaning that is intended to be clarified, there is a kind of wonderful consistency between the words in a single sentence and between the letters in a single word. The truth is that the Qur'anic words have a role and necessity in the context to direct the meaning. It also has a role in matching the rhythm without dominating the other or subjecting the rhythm to one of the two things. In the following examples, we see the interest of the Qur'anic compositions in choosing the appropriate word with a specific tone to perform its function of rhythm, and at the same time, it performs its role in depicting, diagnosing and clarifying the meaning in the perfect way. In addition, look at the word (plow) (حرث) as metaphor for women instead of words like land (الأرض) or the field (الحقل) or the crops (الزرع) and other synonyms, as what Almighty Allah said,

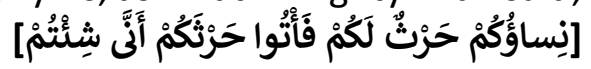

Your wives are as a tilth unto you so approach your tilth when or how ye will (al-quraan, AlBaqarah: 223). Perhaps the selection of this word over others because of the slight touch of the euphemism in that similarity between the connection of the farmer with his tillage and the link between the husband and his wife in this particular aspect. Moreover, between that plant that the plow brings out and that plant (baby) that the husband brings out, and what is in both of them of increasing, growth and cultivation. Know that the Noble Qur'an deals with synonymous words, the most accurate in directing the meaning, the most complete in depicting and characterizing the image, the most beautiful and the melodious in rhythm and weight in relation to its counterparts. In addition to choosing the appropriate word to perform the specific meaning, the Qur'anic composition is concerned with rhythm and harmony in 
pronunciation and melody. Therefore, the word is brought and placed in a specific spot in the phrase. Therefore, that if it changes its placement in advance, delay or omission, that verbal consistency and that special weight would be disturbed. In the Almighty's saying,

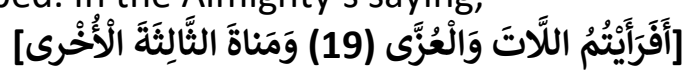

So have you considered al-Lat and al-'Uzza? (Moreover,) Manat, the third - the other one? (al-quraan, An-Najm: 19-20). See if the word (the other) (الُْْْخرىى) was omitted, the comma would be missed and the rhythm would be affected. In addition, if it was said, "Have you seen Al-Lat, Al-Uzza, (Moreover,) Manat, the third by omitting the word (the third) (الثالثة), then the rhythm would be lost as well. Likewise, the Almighty Allah said,

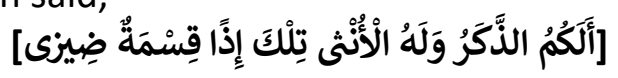

Is the male for you and for Him the female? That, then, is an unjust division. (al-quraan, AnNajm: 22). If the verse was said by deleting the word (That, then) (إذإًا), then the straight rhythm of this word would be disturbed. It is as if these words and letters are arranged and weighted by a highly sensitive scale inclined by the slightest movements and vibrations. Then pau attention to see the unique Qur'anic style, which in the terminology of the experts of science of Al-Balaghah is a method of choosing and composing words to express meanings with the intention of clarification and influence, or it, is the verbal expressions that are coordinated to perform the meanings. The Qur'anic style: It is his unique way of composing its words and choosing its words (Al-Zarqani, 2017, 2/ 199). Scholars both former and modern have agreed that the Qur'an has its own style that is different from the styles of Arabs in writing, rhetoric and composition. The sophisticated Arabs were aware of this distinction in the Qur'anic style from other styles. Muslim narrated that,

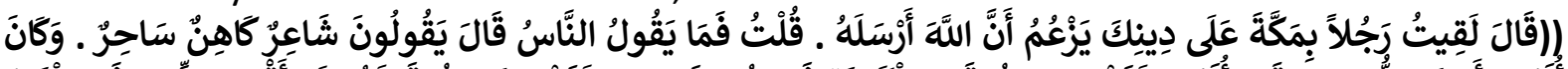

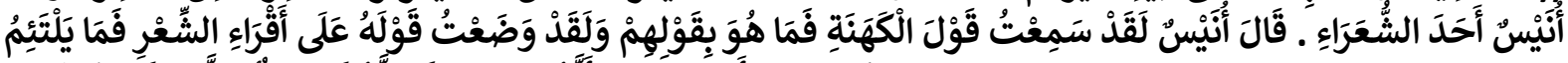

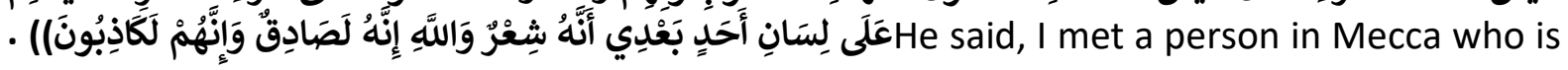
on your religion and he claims that verily it is Allah Who has sent him. I said, what do the people say about him? He said, they told me that he is a poet, a Kahin (parson), or a magician. Unais who was himself one of the poets said. I have heard the words of a Kahin (parson) but his words in no way similar to their (words). In addition, I also compared his words to the verses of poets but any poet cannot utter such words. By Allah, he is truthful and they are liars. (Muslim, 2008, 7/ 153).

\section{Unique Quranic style}

Scholars have highlighted the advantages of the Qur'anic style that are unique to them among other speeches, and this appears in the following points:

\section{Flexibility and Compliance with Interpretation}

We find in the Qur'anic style flexibility in interpretation and compliance with change, so that no style can match it. This flexibility in interpretation does not tolerate conflicting or contradictory opinions. However, flexibility makes it broad significance. The Qur'anic style heals the hearts of the common people and suffices the special and expert ones. Its near appearance guides the masses and the majority of the people and fills the emptiness and gap of their souls with encouragement, intimidation, and the striking beauty in its expressions and manifests. Moreover, its deep interior satisfies the philosophers' appetite for more wisdom and thought, untying and unstring the complicated knots they have related to origin of the universe, its limit, its system, the accuracy of its creation and its creativity. This flexibility is one of the reasons for the immortality of the Qur'an, as the Arabic techniques and methods 
throughout fourteen centuries have undergone a lot of verbal and mental change and varieties. Nevertheless, the Qur'an remained immortal, with its distinct style and unique characteristics that is being renewed with the centuries and it has become a wonderful impact on the progression of generations to these days and until the doomsday.

\section{Adopting the Qur'anic Method, the Figurative Method of Expression}

One of the prominent features of the Qur'anic style is its adoption of the pictorial method to express the meanings and ideas that it wants to clarify, whether they are abstract mental meanings, ancient stories, scenes of the Day of Resurrection and other fields. The Qur'anic style carries its next to the atmosphere of the image, as if looking at the details of the hologram in front of it. It was as if the scene was taking place in front of it alive and moving. Undoubtedly, the idea or meaning that is intended to be clarified is closer to understanding and clearer in the mind than if the meaning was conveyed abstractly from those living images. It suffices to clarify the feature that we visualize all of these meanings in their abstract forms and then compare them with the image in which the Noble Qur'an put it. For example, the meaning of a strong aversion and disliking to the call of faith: If we want to visualize this meaning abstract in the mind, we can say, They are most averse to the call of faith, so the mind alone fills the meaning of aversion in coldness and silence. Let us take a closer look at the Qur'anic style as it depicts this meaning for us in this amazing and extra ordinary picture:

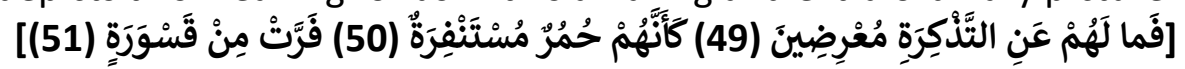

Then what is [the matter] with them that they are, from the reminder, turning away. As if, they were alarmed donkeys, fleeing from a lion. (al-quraan, Al Muddaththir 49-51). The mind has the sense of sight, the faculty of imagination, the emotion of sarcasm and the sense of glamour and beauty: mockery of those (unbelievers) who flee as zebras flee from a lion for nothing but because they call to faith. Moreover, the beauty that is depicted in the movement of the image when the imagination fills it up in a framework of nature in which the donkeys stray, followed by lion. The expression here stirs the reader's feelings and energizes himself with the image that was conveyed to him. In addition, within it mockery of those who turned their back and avoided to listen to the call of faith. The meaning of the powerlessness of the gods that the polytheists worship besides one almighty! It can be performed in several abstract mental expressions, such as saying that what you worship except one Allah are incapable of creating the most despicable thing. Thus meaning up to mind abstract faded and faint but pictorial expression plays in this image such as Almighty Allah said,

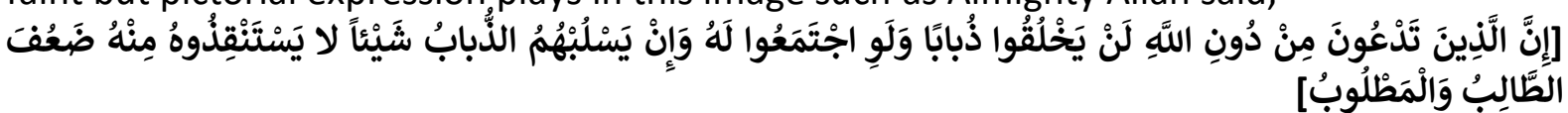

Indeed, those you invoke besides Allah will never create [as much as] a fly, even if they gathered for that purpose. Moreover, if the fly should steal away from them a [tiny] thing, they could not recover it from him. Weak are the pursuer and pursued. (al-quraan, Hajj: 73). He characterizes this meaning and emerges in these successive animated images: They cannot create even a fly (first), even if they All get together for it (second). Moreover, if the fly should steal away from them a [tiny] thing, they could not recover it from him (third). In addition, the association between the word (الطالب) and the (المطلوب) is Weak are the pursuer and pursued, (fourth). The miserable weakness provokes stinging ridicule and humiliating contempt in the soul. these gods would not create a fly even if they gathered for it. The flies are small and despicable, but the miraculousness in their creation is the same miraculousness of creating the camel and the elephant; It is the miracle of life in which the giant fleshy and the lean and skinny are equal. The artistic image here is the link between the sanctity of the 
alleged and so-called gods, as they were placed in the minds of their adherents in the most sacred image. Moreover, the link between them and a despicable little creature. It was not satisfied with this connection, but gathered for these creature huge crowds, and they were still unable to create it. Then in the image that is imprinted in their mind of those flies after the flies stole away from them a [tiny] thing and their failure with their followers from this rescue.

\section{Conclusion}

After we went through this valuable research, we came to the following results:

First: The uniqueness of the Qur'anic style with these features is evidence of its divine source, so the style is nothing but an intellectual image of its creator.

Second: The Arab, who has been connoisseur of beauty of speech, has grasped the distinctive style of the Qur'an. They knew that the reason for this distinction is that the Qur'an is from a source other than human speech and from an uncreated being. So distinguish the technique from the techniques of the creature. As long as the power of creation and creativity from nothingness is not within the power of humans, but rather all creatures, none of them will be able to find a method that resembles or approaches the Qur'anic method.

Third: Not to imitate the Qur'an: Perhaps this realization is what prevented the wise, eloquent and linguists from all corners of Arab from imitating the Qur'an. Moreover, whoever imitated it became a laughingstock among the people because he tried to deviate from his nature, himself and his psyche to imitating the Divine Self.

\section{References}

Al-Quraan Al-Karim.

Abdelgelil, M. F. M. (2020). Grammarians' Critique of Qur'anic Qira'at. International Journal of Academic Research in Business and Social Sciences, 10(11), 1225-1231.

Abdelgelil, M. F. M. (2020). Solving the Quranic Issues with Quranic Qira'at, International Journal of Academic Research in Business and Social Sciences, 10(12), 36-42.

Abdelgelil, M. F. M., Al-Janayni, M. U., Baru, R., Hamzah, M. S., Razali, M. A. T. M., \& Ismail, F. Z. (2018). Tawjih Al-Qira'at Based on Inscription, Language, and Unusual Modes of Recitation According to Ibn Zanjalah. International Journal of Academic Research in Business and Social Sciences, 8(10), 362-370.

Abdelgelil, M. F. M., Daud, N. B., Omar, N. B., Ismail, F. Z. B., \& Wahab, A. H. B. A. (2018). Taujeeh Al-Qira'at Using Qur'an, Hadith and Poetry according to Ibn Zanjalah. International Journal of Academic Research in Business and Social Sciences, 8(10), 371-379.

Abdelgelil, M. F. M., Musolin, M. H., Serour, R. O. H., Abdullah, M. S., \& Noor, M. N. M. (2018). Law and Moral Values in the Holy Quran. International Journal of Academic Research in Business and Social Sciences, 8(11), 445-451.

Abdelgelil, M. F. M., Hassan, A., Yusof, N. H., Idris, M. F. H., Hasan, A. F., \& Ramadan, A. A. (2020). Defending the Quran in the Study of Tawjeeh Al-Qira'at, International Journal of Management, 11(10), pp. 101-104.

Abdelgelil, M. F. M., Razali, M. A., Hassan, A., Hasan, A. F., Idris, M. F. H., \& Masoud, A. S. (2020). Quranic Inimitability in Quranic Qiraat, International Journal of Management, 11(10), pp. 117-121.

Al-Khafajim, A. (1894). Sir al-fasahah. Cairo: maktabah Mustafa Muhammad.

Al-Zarqani, M. (2017). Manahil al-irfan. Cairo: almaktabah al taufiqyyah. 
Ayyad, M. (1421). Al-shifa fi ma'rifat huquq al-mustafa. Bairut: dar al kutub al ilmiyyah. Badi', Z. (1998). Isharat al-I'jaz fi mazan al-I'jaz. Cairo: suzli.

Ibn Al-Qayyim, M. (1988). Al fawai'd al mushawwiqah. Bairut: dar al kutub al ilmiyyah. Ibn Atiyyah, A. (1422). Al-muharrar al-wajiz. Bairut: dar al kutub al ilmiyyah.

Ibn Katheer, I. (2007). Tafsir al quraan al azim. Bairut: dar arrisalah.

Ibn Manzoor, M. (1414). Lisan al-arab. Bairut: dar sadir.

Muhammad, M. (2007), Mabahith fi I'jaz al-quraan. Cairo: dal al muslim. 